\title{
Intracerebroventricular Administration of Metformin Inhibits Ghrelin-Induced Hypothalamic AMP-Kinase Signalling and Food Intake
}

\author{
Darko Stevanovic $^{a}$ Kristina Janjetovic $^{\text {b, d }}$ Maja Misirkic ${ }^{b, d} \quad$ Ljubica Vucicevic $^{\text {b, } d}$ \\ Mirjana Sumarac-Dumanovic ${ }^{c}$ Dragan Micic $^{c}$ Vesna Starcevic $^{a}$ \\ Vladimir Trajkovic ${ }^{b}$ \\ Institutes of a Medical Physiology, ${ }^{b}$ Microbiology and Immunology, and 'Endocrinology, Diabetes and Diseases of \\ Metabolism, School of Medicine, and 'Institute for Biological Research 'Sinisa Stankovic', University of Belgrade, \\ Belgrade, Serbia
}

\section{Key Words}

Metformin · Ghrelin · Food intake · Hypothalamus • AMPK

\begin{abstract}
Background/Aims: The antihyperglycaemic drug metformin reduces food consumption through mechanisms that are not fully elucidated. The present study investigated the effects of intracerebroventricular administration of metformin on food intake and hypothalamic appetite-regulating signalling pathways induced by the orexigenic peptide ghrelin. Methods: Rats were injected intracerebroventricularly with ghrelin $(5 \mu \mathrm{g})$, metformin $(50,100$ or $200 \mu \mathrm{g})$, 5 -amino-imidazole-4-carboxamide 1- $\beta$-D-ribofuranoside (AICAR, $25 \mu \mathrm{g}$ ) and L-leucine $(1 \mu \mathrm{g})$ in different combinations. Food intake was monitored during the next $4 \mathrm{~h}$. Hypothalamic activation of AMP-activated protein kinase (AMPK), acetyl-CoA carboxylase (ACC), regulatory-associated protein of mTOR (Raptor), mammalian target of rapamycin (mTOR) and p70 S6 kinase 1 (S6K) after $1 \mathrm{~h}$ of treatment was analysed by immunoblotting. Results: Metformin suppressed the increase in food consumption induced by intracerebroventricular ghrelin in a dose-dependent manner. Ghrelin increased phosphorylation of hypothalamic AMPK and its targets ACC
\end{abstract}

and Raptor, which was associated with the reduced phosphorylation of mTOR. The mTOR substrate, S6K, was activated by intracerebroventricular ghrelin despite the inhibition of mTOR. Metformin treatment blocked ghrelin-induced activation of hypothalamic AMPK/ACC/Raptor and restored mTOR activity without affecting S6K phosphorylation. Metformin also reduced food consumption induced by the AMPK activator AICAR while the ghrelin-triggered food intake was inhibited by the mTOR activator L-leucine. Conclusion: Metformin could reduce food intake by preventing ghrelin-induced AMPK signalling and mTOR inhibition in the hypotalamus.

Copyright $\odot 2012$ S. Karger AG, Basel

\section{Introduction}

Metformin [(1-(diaminomethylidene)-3,3-dimethylguanidine] is an antihyperglycaemic drug widely used for the management of type 2 diabetes [1]. The glucoregulatory properties of metformin are mainly attributed to reduced hepatic glucose production and augmented glucose uptake by the peripheral tissues [1]. Metformin has also been suggested to reduce weight in diabetic and non-

\section{KARGER \\ Fax +4161306 1234 \\ E-Mail karger@karger.ch}

www.karger.com (c) 2012 S. Karger AG, Basel

0028-3835/12/0961-0024\$38.00/0

Accessible online at:

www.karger.com/nen
Vladimir Trajkovic

Institute of Microbiology and Immunology, School of Medicine

University of Belgrade, Dr. Subotica 1

RS-11000 Belgrade (Serbia)

Tel. +381 113643 233, E-Mail vtrajkovic@ med.bg.ac.rs 
diabetic patients, in contrast to sulphonylureas, thiazolidinediones and insulin, which all induce weight gain [2]. The positive effect of metformin on weight control has been associated with reduced food intake both in humans and experimental animals [3-9], but the mechanisms responsible for the metformin-mediated reduction of food consumption have not been fully clarified. Consistent with the ability of orally administered metformin to readily cross the blood-brain barrier [10], some recent data suggest that its anorexigenic effect might result from a direct action on the hypothalamic centres regulating satiety and feeding [11-13]. In diet-induced obese rats, metformin enhanced the hypothalamic phosphorylation of STAT3 induced by acute intracerebroventricular administration of the anorexigenic hormone leptin [11] and increased hypothalamic leptin receptor expression [12]. Additionally, metformin reduced glucose deprivationtriggered release of the potent orexigenic mediator neuropeptide Y (NPY) in primary hypothalamic neuronal cell cultures [13].

Peripheral metabolic effects of metformin at least partly depend on the stimulation of AMP-activated protein kinase (AMPK) [14, 15], an intracellular energy sensor that is activated by raising AMP and acts by switching on ATP-generating catabolic pathways while switching off ATP-requiring anabolic processes [3]. However, the same dose of intraperitoneally injected metformin that readily activated hepatic AMPK, failed to increase hypothalamic AMPK phosphorylation in rats [16]. Moreover, metformin completely blocked glucose deprivation-induced AMPK phosphorylation in rat primary hypothalamic neurons in vitro [13], suggesting a different regulation of central and peripheral AMPK by this antidiabetic drug.

Ghrelin is a 28 -amino-acid peptide that promotes food intake [17-20] mainly by acting on hypothalamic NPY and agouti-related protein systems [21]. It has been suggested that the orexigenic action of ghrelin is mediated by stimulation of AMPK $[22,23]$, which controls the feeding behaviour through integration of orexigenic and anorexigenic signals $[23,24]$. The intracellular signals downstream of AMPK activation include phosphorylation of regulatory-associated protein of the mammalian target of rapamycin (mTOR) (Raptor) and subsequent inactivation of mTOR and its target p70 S6 kinase 1 (S6K) [25]. The activation of hypothalamic mTOR/S6K has been proposed as an important anorexigenic signal [2628 ], thus making plausible that the orexigenic action of ghrelin might involve central AMPK-mediated mTOR/ S6K inactivation. While metformin has recently been found to increase plasma ghrelin levels in patients with type 2 diabetes [29], the effects of metformin on ghrelininduced food intake and hypothalamic AMPK/mTOR signalling have not been investigated.

Based on the above findings, we hypothesized that metformin could reduce food intake by inhibiting AMPK and consequently restoring mTOR/S6K activity in the hypothalamus. To test this assumption, we examined the influence of centrally applied metformin on ghrelin-triggered acute increase in food intake and hypothalamic AMPK/mTOR signalling.

\section{Materials and Methods}

\section{Animal Preparation}

Eight-week-old male Wistar rats (body weight $200 \pm 20 \mathrm{~g}$ ) were obtained from the Institute of Biomedical Research Galenika (Belgrade, Serbia). They were kept in individual cages under a 12:12 h light/dark cycle, at $22 \pm 2{ }^{\circ} \mathrm{C}$, and were accustomed to daily handling for 2 weeks (body weight $252 \pm 15 \mathrm{~g}$ ). The animals were anaesthetized with intramuscular ketamine (50 mg/kg; Pfizer, New York, N.Y., USA) -xylazine ( 80 mg/kg; Bayer, Leverkusen, Germany) and equipped with a headset for intracerebroventricular injection, consisting of a silastic-sealed 20 -gauge cannula positioned in the right lateral cerebral ventricle $(1 \mathrm{~mm}$ posterior and $1.5 \mathrm{~mm}$ lateral to the bregma, and 3 $\mathrm{mm}$ below the cortical surface) [30]. A small stainless steel anchor screw was placed at a remote site on the skull. The cannula and screw were cemented to the skull with standard dental acrylic. Following surgery, the animals received a single subcutaneous dose of $0.28 \mathrm{mg} / \mathrm{kg}$ buprenorphin (Reckitt Benckiser Healthcare, Mannheim, Germany) and 1 week of recovery was allowed before the experiments. Only animals demonstrating progressive weight gain after surgery were used in subsequent experiments. All rats had ad libitum access to rodent chow (D.D. Veterinarski zavod Subotica, Subotica, Serbia) and water during experimental testing.

\section{Experiment 1}

Effect of Intracerebroventricular Metformin on

Ghrelin-Induced Food Intake

In this experiment, the rats were treated intracerebroventricularly with $5 \mu \mathrm{g}$ ghrelin (Bachem, Weil am Rhein, Germany), metformin hydrochloride (50, 100 or $200 \mu \mathrm{g}$; 99.9\% Hemofarm, Vrsac, Serbia) or ghrelin and metformin ( $n=6$ in each group). The orexigenic concentration of ghrelin $(5 \mu \mathrm{g})$ was chosen based on a previous study [23]. The concentrations of metformin (50-200 $\mu \mathrm{g})$ which did not cause overt neurotoxicity after a single intracerebroventricular injection were selected based on previous reports $[16,31]$. Both ghrelin and metformin were applied in $2 \mu \mathrm{l}$ of phosphate-buffered saline (PBS; Sigma-Aldrich, St. Louis, Mo., USA) using a 5- $\mu$ l Hamilton syringe. Metformin was administered $30 \mathrm{~min}$ before ghrelin. The animals in the ghrelin-only group received $2 \mu \mathrm{l}$ PBS $30 \mathrm{~min}$ before treatment while those in the metformin-only group received $2 \mu \mathrm{l}$ PBS $30 \mathrm{~min}$ after the treatment. Control animals received $2 \times 2 \mu \mathrm{l}$ PBS. Food intake was measured each hour up to $4 \mathrm{~h}$ after the second injection. 


\section{Experiment 2}

Effect of Intracerebroventricular Metformin on

Ghrelin-Induced AMPK/mTOR Signalling

The rats were treated as described in experiment $1(n=6$ in each group), but metformin was used at the concentration of 100 $\mu \mathrm{g}$. One hour after the last injection, the rats were killed by decapitation under deep isoflurane anaesthesia; hypothalamic tissues were collected and immediately frozen in liquid nitrogen for immunoblot analysis.

\section{Experiment 3}

Effect of Intracerebroventricular Metformin on

5-Aminoimidazole-4-Carboxamide 1- $\beta$-D-RibofuranosideInduced Food Intake

Rats were treated as described in experiment $1(n=5$ in each group), except that 5 -aminoimidazole-4-carboxamide $1-\beta$-D-ribofuranoside (AICAR; Sigma-Aldrich) (25 $\mu \mathrm{g}$ in $2 \mu \mathrm{l}$ dimethylsulphoxide, DMSO) was used instead of ghrelin while metformin was used at $100 \mu \mathrm{g}$. The orexigenic dose of AICAR was chosen based on a previous study [23]. The animals in the metforminonly group received $2 \mu \mathrm{l}$ DMSO $30 \mathrm{~min}$ after metformin treatment while control animals received $2 \mu \mathrm{l}$ PBS $+2 \mu \mathrm{l}$ DMSO. Food intake was measured each hour up to $4 \mathrm{~h}$ after the second injection.

\section{Experiment 4}

Effect of L-Leucine on Ghrelin-Induced Food Intake

Rats were treated as described in experiment $1(n=5$ in each group), except that L-leucine (Sigma-Aldrich) (1 $\mu$ g in $2 \mu \mathrm{l} \mathrm{PBS}$ ) was used instead of ghrelin. Food intake was measured each hour up to $4 \mathrm{~h}$ after the second injection. The concentration of intracerebroventricular L-leucine was selected based on its ability to suppress post-fasting food intake in rats [32].

\section{Immunoblot Analysis}

Western blot followed by protein detection with specific antibodies was used to assess phosphorylation (activation) of various members of the AMPK/mTOR signalling pathway [AMPK, acetyl-CoA carboxylase (ACC), Raptor, mTOR and S6K]. The hypothalamic tissue was lysed in a RIPA buffer (Sigma-Aldrich) on ice for $30 \mathrm{~min}$, centrifuged at $14,000 \mathrm{~g}$ for $15 \mathrm{~min}$ at $4^{\circ} \mathrm{C}$, and the supernatants were collected. Equal amounts of total protein from each sample (10 $\mu \mathrm{g}$ for actin blot and $25 \mu \mathrm{g}$ for all other proteins) were separated by SDS-PAGE and transferred to a nitrocellulose membrane (Bio-Rad, Marnes-la-Coquette, France). All blots were performed on separate gels. Following incubation with primary antibodies against phospho-AMPK $\alpha$ (Thr172), AMPK, phosphoACC (Ser79), phospho-Raptor (Ser792), Raptor, phospho-mTOR (Ser2448), phospho-S6K (Thr389), S6K or actin (Cell Signaling Technology, Beverly, Mass., USA) and peroxidase-conjugated goat anti-rabbit IgG (Jackson ImmunoResearch Laboratories, West Grove, Pa., USA) as the secondary antibody, specific protein bands were visualized using enhanced-chemiluminescence reagents for Western blot analysis (Amersham Pharmacia Biotech, Piscataway, N.J., USA). The signal intensity was determined by densitometry using Image $J$ software and the results were presented as phospho/total protein signal ratio, which was arbitrarily set to 1 in control.
Statistical Analysis

The data obtained from each sample were averaged per experimental group and the standard deviation of the mean (SD) was calculated. A one-way analysis of variance (ANOVA), followed by a Student-Newman-Keuls test for multiple comparisons, was used to assess differences between the groups. A p value of less than 0.05 was considered statistically significant.

\section{Results}

\section{Centrally Applied Metformin Inhibits}

Ghrelin-Induced Food Intake

We first investigated the ability of centrally applied metformin to influence the orexigenic effect of ghrelin. In the absence of ghrelin, intracerebroventricular administration of metformin $(50,100$ or $200 \mu \mathrm{g})$ did not significantly affect food intake (fig. 1a). Expectedly, intracerebroventricular injection of ghrelin $(5 \mu \mathrm{g})$ caused a time-dependent increase in cumulative food intake over the 4-hour post-injection period (fig. 1b). Pretreatment with metformin reduced the orexigenic effect of ghrelin at each time point in a dose-dependent manner (fig. 1b). These data demonstrate that metformin can counteract the orexigenic effect of ghrelin at the hypothalamic level.

\section{Metformin Modulates Hypothalamic AMPK/mTOR}

Signalling in Ghrelin-Treated Rats

We next investigated the influence of metformin on hypothalamic AMPK/mTOR signalling in ghrelin-treated rats. Central administration of ghrelin $(5 \mu \mathrm{g})$ increased phosphorylation of hypothalamic AMPK and its downstream targets ACC and Raptor, which was associated with reduced phosphorylation of $\mathrm{mTOR}$, but increased activation of its direct substrate S6K (fig. 2). While treatment with metformin $(100 \mu \mathrm{g})$ did not alter hypothalamic AMPK/mTOR signalling in the absence of ghrelin, it significantly suppressed ghrelin-induced activation of AMPK/ACC/Raptor and restored the phosphorylation of ghrelin-inactivated mTOR without affecting S6K phosphorylation (fig. 2). Therefore, centrally applied metformin can interfere with hypothalamic AMPK/ mTOR signalling, but not with S6K activation in rats treated with intracerebroventricular ghrelin.

\section{Metformin Inhibits Food Intake Induced by AMPK Activator AICAR}

We next assessed whether metformin could inhibit food intake induced by intracerebroventricular injection of AICAR, a pharmacological AMPK activator with orexigenic activity in rats [23]. In comparison with con- 


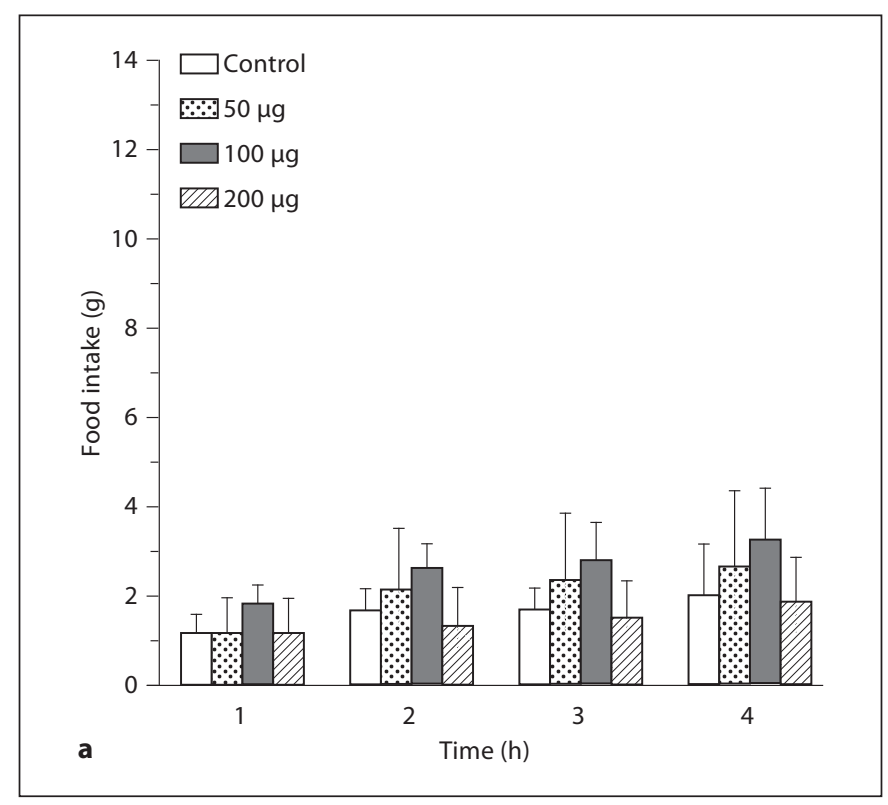

Fig. 1. Centrally applied metformin inhibits ghrelin-induced food intake. Rats ( $n=6$ per group) were injected intracerebroventricularly with PBS (control; a, b), 50-200 $\mu$ g metformin (a), $5 \mu \mathrm{g}$ ghrelin (b), or ghrelin and metformin (b). Cumulative food intake was

trol animals, rats treated with AICAR $(25 \mu \mathrm{g})$ consumed more food during the 4-hour follow-up period, with a significant increase in food intake observed after 3 and $4 \mathrm{~h}$ (fig. 3). AICAR-induced hyperphagia was significantly reduced at both time points by co-administration of metformin $(100 \mu \mathrm{g})$.

\section{mTOR Activator L-Leucine Inhibits Ghrelin-Induced Food Intake}

Finally, we tested the ability of L-leucine, an mTOR activator with anorexigenic activity [32], to affect ghrelin-mediated food intake. Treatment with ghrelin $(5 \mu \mathrm{g}$, i.c.v.) induced a sustained increase in food consumption for $4 \mathrm{~h}$ after injection (fig. 4). Intracerebroventricularly injected L-leucine $(1 \mu \mathrm{g})$ did not interfere with food intake in control animals (fig. 4). On the other hand, it significantly reduced the ghrelin-triggered increase in food consumption at each of the time points (fig. 4).

\section{Discussion}

The present study, for the first time, demonstrates the ability of centrally applied metformin to suppress acute ghrelin-induced increase in food intake. The observed ef-

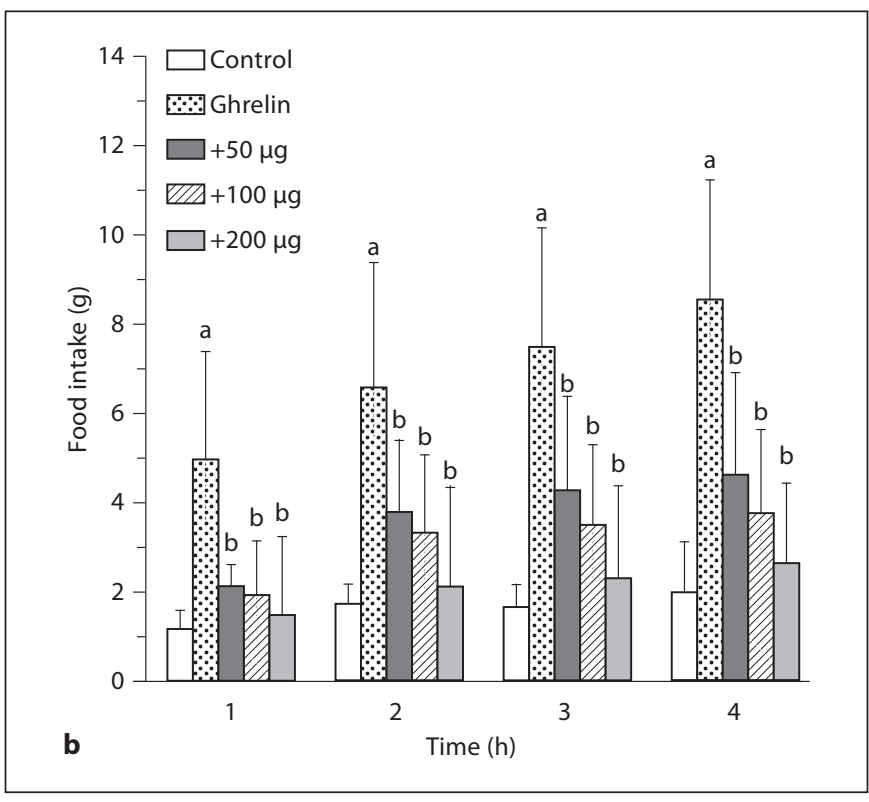

measured during $4 \mathrm{~h}$ at the indicated time points. The results from the same experiment (presented separately for clarity) are mean $\pm \mathrm{SD}$ values $\left({ }^{\mathrm{a}} \mathrm{p}<0.05\right.$ and ${ }^{\mathrm{b}} \mathrm{p}<0.05$ refer to control and ghrelintreated rats, respectively). fect was associated with the inhibition of ghrelin-triggered activation of hypothalamic AMPK, as well as with the restoration of mTOR activity. These data suggest that the previously well-documented anorexigenic effect of metformin [3-9] could, at least partly, be mediated at the hypothalamic level through interference with ghrelin-induced orexigenic AMPK signalling.

Our hypothesis that the appetite-reducing effect of metformin could be due to suppression of AMPK activation is consistent with the proposed role of this intracellular energy sensor in ghrelin-mediated food intake [22, 23]. In accordance with the present study, both central and systemic ghrelin administration activate hypothalamic AMPK $[22,23]$, and experimental genetic activation or inactivation of hypothalamic AMPK leads to increased or decreased food intake, respectively [24]. It has been shown that the calcium/calmodulin-dependent protein kinase 2 and sirtuin 1/p53 pathway are required for hypothalamic AMPK activation by ghrelin [33-35], but the appetite-controlling signals downstream of AMPK activation have not been fully delineated. mTOR is a plausible AMPK target which has been suggested to mediate the anorexigenic effects of leptin [26-28], an important adipocyte-derived negative regulator of energy balance that counteracts the metabolic actions of 
Fig. 2. Metformin modulates hypothalamic AMPK/mTOR signalling in ghrelintreated rats. Rats ( $n=6$ per group) were injected intracerebroventricularly with PBS (control), metformin $(100 \mu \mathrm{g})$, ghrelin (5 $\mu \mathrm{g})$, or ghrelin and metformin. After $1 \mathrm{~h}$, the levels of phosphorylated (p) and total AMPK, ACC, Raptor, mTOR and S6K were assessed by immunoblotting, with actin used as a loading control. The representative blots are presented in a while the data in $\mathbf{b}$ are mean \pm SD values $(n=6)$ of phospho/total protein signal ratio $\left({ }^{\mathrm{a}} \mathrm{p}<\right.$ 0.05 and ${ }^{b} \mathrm{p}<0.05$ refer to control and ghrelin-treated rats, respectively).

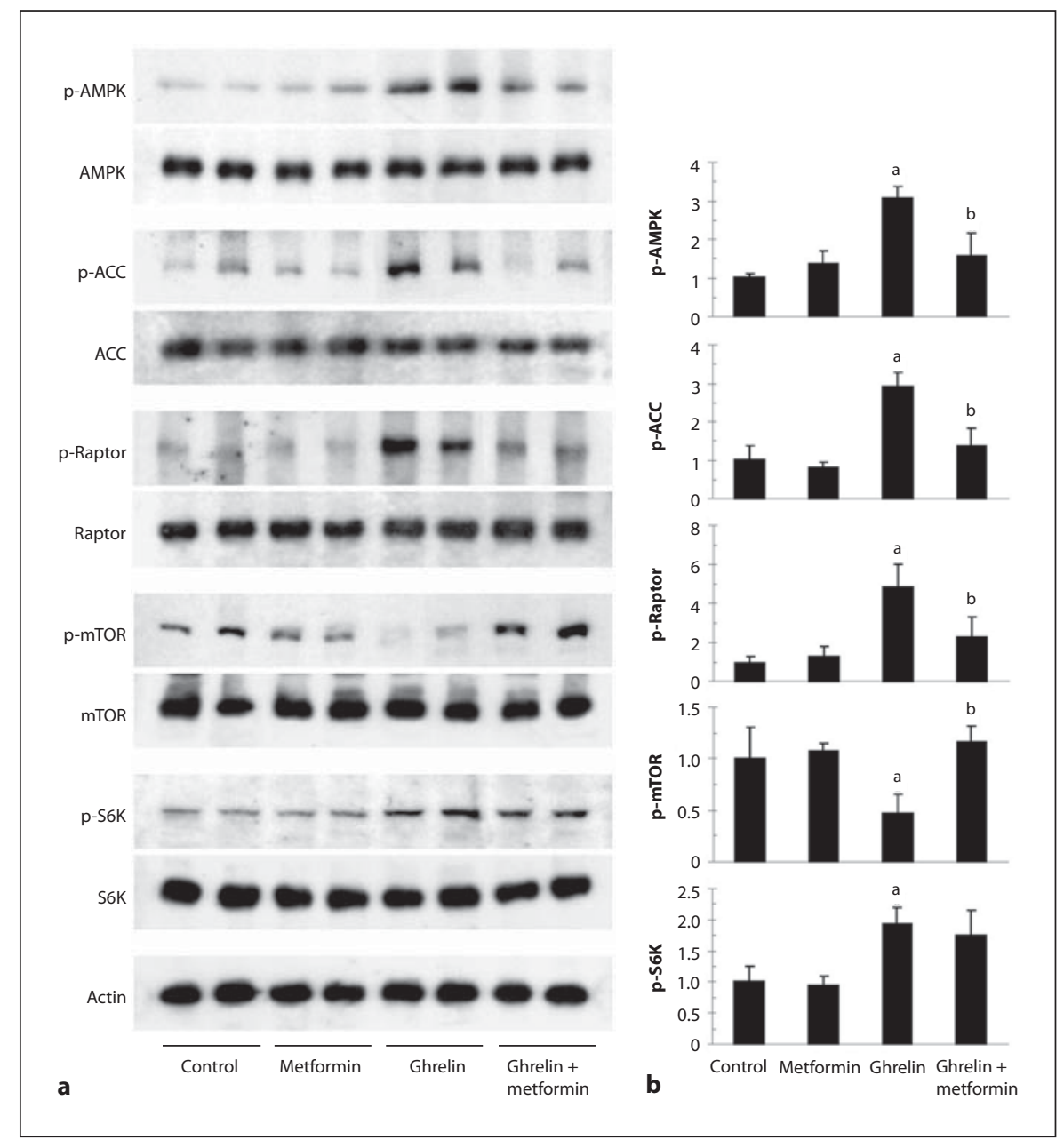

ghrelin [36]. Our findings that ghrelin-induced hyperphagia coincided with downregulation of mTOR activity and was suppressed by the mTOR activator L-leucine are indeed consistent with the proposed role of hypothalamic mTOR as an anorexigenic signal [26-28]. Moreover, in our study, metformin-mediated blockade of ghrelin-triggered food intake and AMPK activation were associated with restoration of hypothalamic mTOR activity, thus indicating that the anorexigenic effect of metformin might depend on interference with AMPKmediated mTOR downregulation in the hypothalamus. This assumption is consistent with the in vitro data demonstrating metformin-mediated AMPK inhibition in glucose-deprived rat primary hypothalamic neurons [13]. However, it seems that the inhibitory effect of metformin on AMPK might be restricted to the hypothalamus or might be species specific as in two recent studies metformin activated AMPK and inhibited mTOR in mouse hypocampal slices and cultured cortical neurons $[37,38]$.

While, as discussed above, metformin might target hypothalamic AMPK/mTOR signalling to block the orexigenic action of ghrelin, it should be noted that the changes in the activation of the mTOR substrate S6K in our experiments did not correlate with the activation status of mTOR. Namely, ghrelin-mediated mTOR downregulation was paradoxically associated with S6K activation, which was not further altered by restoring mTOR phosphorylation with metformin. These data actually concur with the recent findings by Villanueva et al. [39], who reported activation of S6K in the arcuate nucleus of mice treated intracerebroventricularly with ghrelin or exposed to fasting, a state associated with an increase in the levels of circulating ghrelin [40, 41]. Moreover, both S6K1- and S6K2-knockout mice responded to ghrelin by increasing food consumption comparably to their wild- 


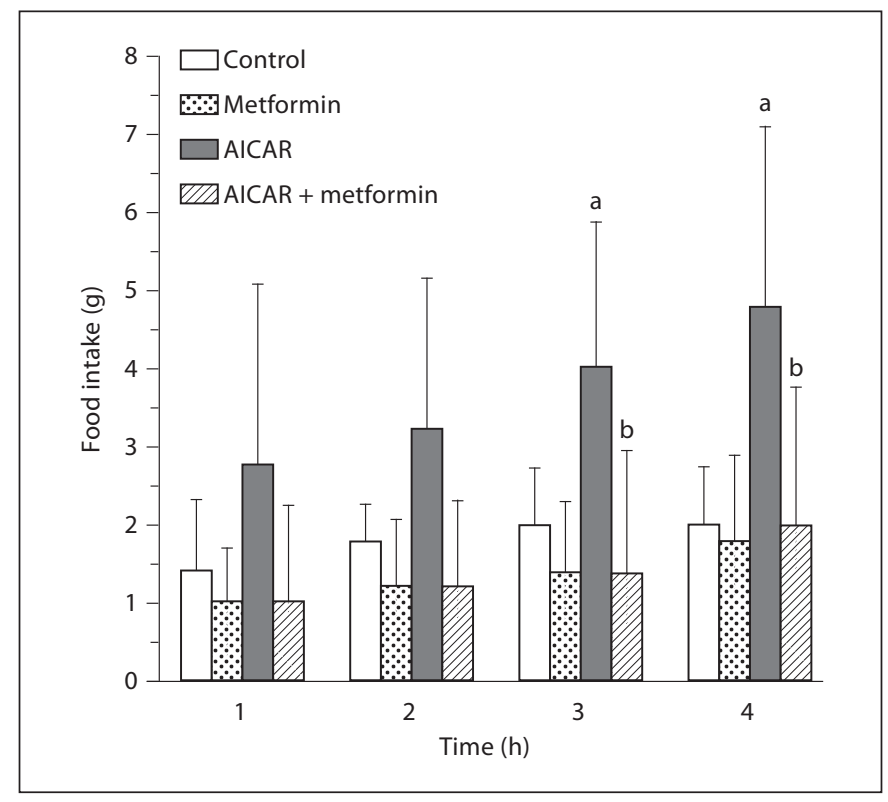

Fig. 3. Metformin inhibits AICAR-induced food intake. Rats ( $\mathrm{n}=$ 5 per group) were injected intracerebroventricularly with PBS (control), metformin $(100 \mu \mathrm{g})$, AICAR $(25 \mu \mathrm{g})$, or AICAR and metformin. Cumulative food intake was measured during $4 \mathrm{~h}$ at the indicated time points. The results are presented as mean \pm $\mathrm{SD}$ values $\left({ }^{\mathrm{a}} \mathrm{p}<0.05\right.$ and ${ }^{\mathrm{b}} \mathrm{p}<0.05$ refer to control and AICARtreated rats, respectively).

type counterparts, indicating that $\mathrm{S} 6 \mathrm{~K}$ modulation is dispensable for ghrelin-induced hyperphagia [Stevanovic et al., submitted for publication]. While the role of hypothalamic S6K in the orexigenic effect of ghrelin remains to be fully elucidated, the dissociated mTOR and S6K activation status in our experiments clearly indicates that ghrelin could activate S6K independently of mTOR. Accordingly, mTOR-independent regulation of S6K has previously been reported [42]. In addition, our data imply that the putative involvement of mTOR inhibition as an orexigenic signal downstream of AMPK is mediated independently of S6K, or that alternatively, mTOR-independent mechanisms are responsible for the orexigenic action of AMPK. The latter assumption is supported by previous demonstration that ghrelin-mediated activation of hypothalamic AMPK increases food intake through a hypothalamic fatty acid oxidation pathway involving ACC/malonyl-CoA, carnitine palmitoyltransferase 1 and uncoupling protein 2 [43-45]. Indeed, we have observed an increase in ACC activation upon intracerebroventricular injection of ghrelin, and this effect was efficiently counteracted by co-administration of metformin. It is therefore possible that hypothalamic ACC and/or other

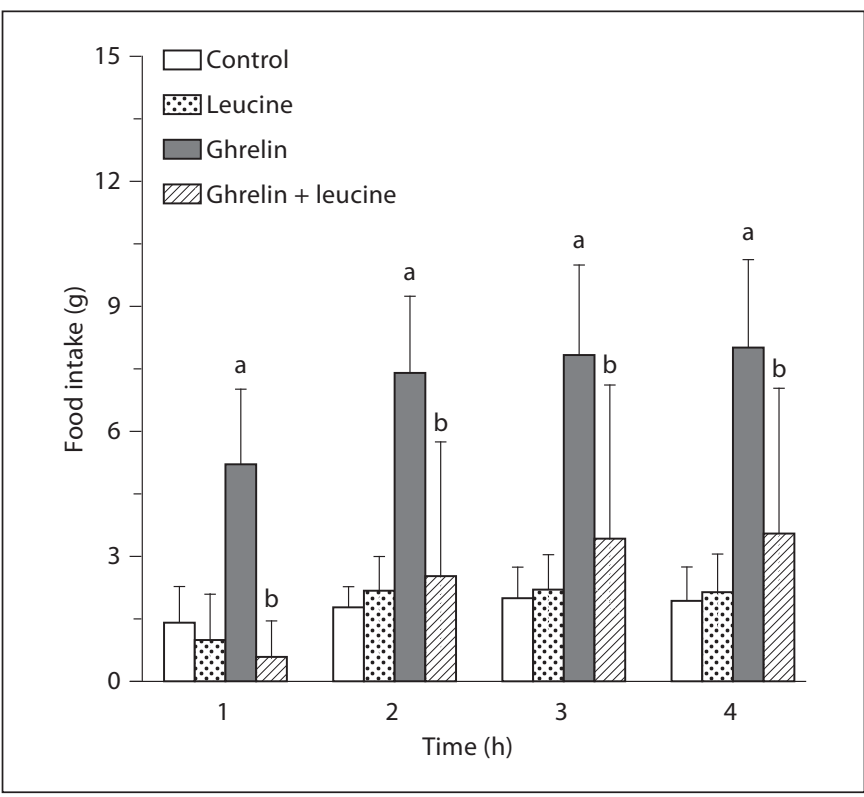

Fig. 4. L-Leucine inhibits ghrelin-induced food intake. Rats ( $\mathrm{n}=$ 5 per group) were injected intracerebroventricularly with PBS (control), L-leucine $(1 \mu \mathrm{g})$, ghrelin $(5 \mu \mathrm{g})$, or ghrelin and L-leucine. Cumulative food intake was measured during $4 \mathrm{~h}$ at the indicated time points. The results are presented as mean \pm SD values $\left({ }^{\mathrm{a}} \mathrm{p}<0.05\right.$ and ${ }^{\mathrm{b}} \mathrm{p}<0.05$ refer to control and ghrelin-treated rats, respectively).

AMPK downstream targets different from mTOR/S6K could be responsible for the anorexigenic action of metformin. In the present study, we did not investigate the interference of metformin with ghrelin orexigenic signals that are further downstream of hypothalamic AMPK activation, such as NPY release. In contrast to the in vitro inhibitory effect of metformin on NPY release by glucose-deprived rat hypothalamic neurons [13], the anorexigenic effect of metformin in genetically obese Zucker rats is independent of the changes in hypothalamic NPY content [46]. We are currently investigating the role of NPY modulation in metformin-mediated suppression of ghrelin-induced hyperphagia.

Finally, it is interesting to note that metformin treatment increased plasma ghrelin concentrations in patients with type-2 diabetes [29]. This is somewhat unexpected considering the orexigenic action of ghrelin [17-20] and the well-documented inhibitory effect of metformin on food intake [3-9]. Our data, however, resolve this discrepancy by demonstrating that metformin could actually block the action of ghrelin in the hypothalamus, thus presumably counteracting the stimulatory effect on circulating ghrelin levels. 
In conclusion, our data indicate a novel mechanism of the anorexigenic action of metformin involving downregulation of ghrelin-induced activation of the AMPK signalling pathway. A different regulation of AMPK activation in the hypothalamus and peripheral tissues might contribute to the beneficial metabolic effects of metformin as peripheral AMPK activation will increase energy expenditure while hypothalamic AMPK inhibition will reduce food intake. It should be noted, however, that the metformin concentrations used in our study and in previous studies [16, 31] seem rather high compared with those applied therapeutically [47]. Nevertheless, lower concentrations of chronically administered metformin might still affect hypothalamic AMPK signalling. There- fore, further studies are required to explore the mechanisms underlying central AMPK downregulation by metformin and its potential therapeutic significance in metabolic disorders.

\section{Acknowledgements}

This study was supported by the Ministry of Science and Technological Development of the Republic of Serbia (grant No. 41025 and 175067). The authors thank Dr. Dragomir Marisavljevic (Hemofarm, Vrsac, Serbia) for kindly providing metformin hydrochloride, Katarina Zivanovic and Marina Halasev-Dikovic for excellent technical support, and Ljubica Harhaji-Trajkovic for critically reading the manuscript.

\section{References}

1 Correia S, Carvalho C, Santos MS, Seiça R, Oliveira CR, Moreira PI: Mechanisms of action of metformin in type 2 diabetes and associated complications: an overview. Mini Rev Med Chem 2008;8:1343-1354.

12 Golay A: Metformin and body weight. Int J Obes (Lond) 2008;32:61-72.

-3 Borst SE, Snellen HG, Lai HL: Metformin treatment enhances insulin-stimulated glucose transport in skeletal muscle of SpragueDawley rats. Life Sci 2000;67:165-174.

4 Glueck CJ, Fontaine RN, Wang P, Subbiah MT, Weber K, Illig E, Streicher P, SieveSmith L, Tracy TM, Lang JE, McCullough P: Metformin reduces weight, centripetal obesity, insulin, leptin, and low-density lipoprotein cholesterol in nondiabetic, morbidly obese subjects with body mass index greater than 30. Metabolism 2001;50:856-861.

5 Kumar VB, Bernardo AE, Vyas K, Franko M, Farr S, Lakshmanan L, Buddhiraju C, Morley JE: Effect of metformin on nitric oxide synthase in genetically obese (ob/ob) mice. Life Sci 2001;69:2789-2799.

6 Lee A, Morley JE: Metformin decreases food consumption and induces weight loss in subjects with obesity with type II non-insulin-dependent diabetes. Obes Res 1998;6: 47-53.

7 Matsui Y, Hirasawa Y, Sugiura T, Toyoshi T, Kyuki K, Ito M: Metformin reduces body weight gain and improves glucose intolerance in high-fat diet-fed C57BL/6J mice. Biol Pharm Bull 2010;33:963-970.

-8 Paolisso G, Amato L, Eccellente R, Gambardella A, Tagliamonte MR, Varricchio G, Carella C, Giugliano D, D’Onofrio F: Effect of metformin on food intake in obese subjects. Eur J Clin Invest 1998;28:441-446.
9 Rouru J, Huupponen R, Pesonen U, Koulu M: Subchronic treatment with metformin produces anorectic effect and reduces hyperinsulinemia in genetically obese Zucker rats. Life Sci 1992;50:1813-1820.

10 Łabuzek K, Suchy D, Gabryel B, Bielecka A, Liber S, Okopień B: Quantification of metformin by the HPLC method in brain regions, cerebrospinal fluid and plasma of rats treated with lipopolysaccharide. Pharmacol Rep 2010;62:956-965.

11 Kim YW, Kim JY, Park YH, Park SY, Won KC, Choi KH, Huh JY, Moon KH: Metformin restores leptin sensitivity in high-fat-fed obese rats with leptin resistance. Diabetes 2006;55:716-724.

12 Aubert G, Mansuy V, Voirol MJ, Pellerin L, Pralong FP: The anorexigenic effects of metformin involve increases in hypothalamic leptin receptor expression. Metabolism 2010;60:327-334.

13 Chau-Van C, Gamba M, Salvi R, Gaillard RC, Pralong FP: Metformin inhibits adenosine $5^{\prime}$-monophosphate-activated kinase activation and prevents increases in neuropeptide $\mathrm{Y}$ expression in cultured hypothalamic neurons. Endocrinology 2007;148:507-511.

14 Zhou G, Myers R, Li Y, Chen Y, Shen X, Fenyk-Melody J, Wu M, Ventre J, Doebber T, Fujii N, Musi N, Hirshman MF, Goodyear LJ, Moller DE: Role of AMP-activated protein kinase in mechanism of metformin action. J Clin Invest 2001;108:1167-1174.

15 Hardie DG: AMPK: a key regulator of energy balance in the single cell and the whole organism. Int J Obes (Lond) 2008;32(suppl 4):S7-S12.
16 Harada S, Fujita-Hamabe W, Tokuyama S: The importance of regulation of blood glucose levels through activation of peripheral 5 -AMP-activated protein kinase on ischemic neuronal damage. Brain Res 2010;1351: 254-263.

17 Druce MR, Wren AM, Park AJ, Milton JE, Patterson M, Frost G, Ghatei MA, Small C, Bloom SR: Ghrelin increases food intake in obese as well as lean subjects. Int J Obes (Lond) 2005;29:1130-1136.

18 Nakazato M, Murakami N, Date Y, Kojima M, Matsuo H, Kangawa K, Matsukura S: A role for ghrelin in the central regulation of feeding. Nature 2001;409:194-198.

19 Tang-Christensen M, Vrang N, Ortmann S, Bidlingmaier M, Horvath TL, Tschöp M: Central administration of ghrelin and agouti-related protein (83-132) increases food intake and decreases spontaneous locomotor activity in rats. Endocrinology 2004; 145: 4645-4652.

20 Tschöp M, Smiley DL, Heiman ML: Ghrelin induces adiposity in rodents. Nature 2000; 407:908-913.

21 Chen HY, Trumbauer ME, Chen AS, Weingarth DT, Adams JR, Frazier EG, Shen Z, Marsh DJ, Feighner SD, Guan XM, Ye Z, Nargund RP, Smith RG, Van der Ploeg LH, Howard AD, MacNeil DJ, Qian S: Orexigenic action of peripheral ghrelin is mediated by neuropeptide $\mathrm{Y}$ and agouti-related protein. Endocrinology 2004;145:2607-2612.

-22 Kola B, Hubina E, Tucci SA, Kirkham TC, Garcia EA, Mitchell SE, Williams LM, Hawley SA, Hardie DG, Grossman AB, Korbonits M: Cannabinoids and ghrelin have both central and peripheral metabolic and cardiac effects via AMP-activated protein kinase. J Biol Chem 2005;280:25196-25201. 
-23 Andersson U, Filipsson K, Abbott CR, Woods A, Smith K, Bloom SR, Carling D, Small CJ: AMP-activated protein kinase plays a role in the control of food intake. J Biol Chem 2004;279:12005-12008.

-24 Minokoshi Y, Alquier T, Furukawa N, Kim YB, Lee A, Xue B, Mu J, Foufelle F, Ferré P, Birnbaum MJ, Stuck BJ, Kahn BB: AMP-kinase regulates food intake by responding to hormonal and nutrient signals in the hypothalamus. Nature 2004;428:569-574.

25 Shaw RJ: LKB1 and AMP-activated protein kinase control of mTOR signaling and growth. Acta Physiol (Oxf) 2009;196:65-80.

26 Blouet C, Ono H, Schwartz GJ: Mediobasal hypothalamic p70 S6 kinase 1 modulates the control of energy homeostasis. Cell Metab 2008;8:459-467.

27 Cota D, Matter EK, Woods SC, Seeley RJ: The role of hypothalamic mammalian target of rapamycin complex 1 signaling in diet-induced obesity. J Neurosci 2008;28:72027208.

28 Cota D, Proulx K, Smith KA, Kozma SC, Thomas G, Woods SC, Seeley RJ: Hypothalamic mTOR signaling regulates food intake. Science 2006;312:927-930.

-29 Doogue MP, Begg EJ, Moore MP, Lunt H, Pemberton CJ, Zhang M: Metformin increases plasma ghrelin in type 2 diabetes. $\mathrm{Br}$ J Clin Pharmacol 2009;68:875-882.

30 Starcevic VP, Morrow BA, Farner LA, Keil LC, Severs WB: Long-term recording of cerebrospinal fluid pressure in freely behaving rats. Brain Res 1988;462:112-117.

31 Petersen JS, DiBona GF: Acute sympathoinhibitory actions of metformin in spontaneously hypertensive rats. Hypertension 1996; 27:619-625.

32 Morrison CD, Xi X, White CL, Ye J, Martin RJ: Amino acids inhibit Agrp gene expression via an mTOR-dependent mechanism. Am J Physiol Endocrinol Metab 2007;293: E165-E171.

- 33 Anderson KA, Ribar TJ, Lin F, Noeldner PK, Green MF, Muehlbauer MJ, Witters LA, Kemp BE, Means AR: Hypothalamic CaMKK2 contributes to the regulation of energy balance. Cell Metab 2008;7:377-388.
Kohno D, Gao HZ, Muroya S, Kikuyama S, Yada T: Ghrelin directly interacts with neuropeptide-Y-containing neurons in the rat arcuate nucleus: $\mathrm{Ca}^{2+}$ signaling via protein kinase $\mathrm{A}$ and $\mathrm{N}$-type channel-dependent mechanisms and cross-talk with leptin and orexin. Diabetes 2003;52:948-956.

35 Velásquez DA, Martínez G, Romero A, Vázquez MJ, Boit KD, Dopeso-Reyes IG, López M, Vidal A, Nogueiras R, Diéguez C: The central Sirtuin 1/p53 pathway is essential for the orexigenic action of ghrelin. Diabetes 2011;60:1177-1185

36 Pinto S, Roseberry AG, Liu H, Diano S, Shanabrough M, Cai X, Friedman JM, Horvath TL: Rapid rewiring of arcuate nucleus feeding circuits by leptin. Science 2004;304: 110-115.

37 Potter WB, O’Riordan KJ, Barnett D, Osting SM, Wagoner M, Burger C, Roopra A: Metabolic regulation of neuronal plasticity by the energy sensor AMPK. PLoS One 2010; 5:e8996.

38 Williams T, Courchet J, Viollet B, Brenman JE, Polleux F: AMP-activated protein kinase (AMPK) activity is not required for neuronal development but regulates axogenesis during metabolic stress. Proc Natl Acad Sci USA 2011;108:5849-5854.

39 Villanueva EC, Münzberg H, Cota D, Leshan RL, Kopp K, Ishida-Takahashi R, Jones JC, Fingar DC, Seeley RJ, Myers MG Jr: Complex regulation of mammalian target of rapamycin complex 1 in the basomedial hypothalamus by leptin and nutritional status. Endocrinology 2009; 150:4541-4551.

40 Moesgaard SG, Ahrén B, Carr RD, Gram DX, Brand CL, Sundler F: Effects of high-fat feeding and fasting on ghrelin expression in the mouse stomach. Regul Pept 2004;120:261267.
41 Toshinai K, Date Y, Murakami N, Shimada M, Mondal MS, Shimbara T, Guan JL, Wang QP, Funahashi H, Sakurai T, Shioda S, Matsukura S, Kangawa K, Nakazato M: Ghrelininduced food intake is mediated via the orexin pathway. Endocrinology 2003;144:15061512.

42 Jaeschke A, Hartkamp J, Saitoh M, Roworth W, Nobukuni T, Hodges A, Sampson J, Thomas G, Lamb R: Tuberous sclerosis complex tumor suppressor-mediated S6 kinase inhibition by phosphatidylinositide-3-OH kinase is mTOR independent. J Cell Biol 2002;159:217-224.

43 Andrews ZB, Liu ZW, Walllingford N, Erion DM, Borok E, Friedman JM, Tschöp MH, Shanabrough M, Cline G, Shulman GI, Coppola A, Gao XB, Horvath TL, Diano S: UCP2 mediates ghrelin's action on NPY/AgRP neurons by lowering free radicals. Nature 2008;454:846-851.

44 López M, Lage R, Saha AK, Pérez-Tilve D, Vázquez MJ, Varela L, Sangiao-Alvarellos S, Tovar S, Raghay K, Rodríguez-Cuenca S, Deoliveira RM, Castañeda T, Datta R, Dong JZ, Culler M, Sleeman MW, Alvarez CV, Gallego R, Lelliott CJ, Carling D, Tschöp MH, Diéguez $\mathrm{C}$, Vidal-Puig A: Hypothalamic fatty acid metabolism mediates the orexigenic action of ghrelin. Cell Metab 2008;7:389-399.

45 Lage R, Vázquez MJ, Varela L, Saha AK, Vidal-Puig A, Nogueiras R, Diéguez C, López M: Ghrelin effects on neuropeptides in the rat hypothalamus depend on fatty acid metabolism actions on BSX but not on gender. FASEB J 2010;24:2670-2679.

46 Rouru J, Pesonen U, Koulu M, Huupponen R, Santti E, Virtanen K, Rouvari T, JhanwarUniyal M: Anorectic effect of metformin in obese Zucker rats: lack of evidence for the involvement of neuropeptide Y. Eur J Pharmacol 1995;273:99-106.

\4 Graham GG, Punt J, Arora M, Day RO, Doogue MP, Duong JK, Furlong TJ, Greenfield JR, Greenup LC, Kirkpatrick CM, Ray JE, Timmins P, Williams KM: Clinical pharmacokinetics of metformin. Clin Pharmacokinet 2011;50:81-98. 